\title{
Molecular Epidemiology of Mycobacterium Tuberculosis Complex at Nekemte Municipality Abattoir, Western Ethiopia
}

\author{
Mezene Woyessa ${ }^{1 *}$, Yasmin Jibril $^{2}$, Gobena Ameni ${ }^{3}$ and Reta Duguma ${ }^{2}$ \\ ${ }^{1}$ School of Veterinary Medicine, Wollega University, Post Box No: 395, Nekemte, Ethiopia \\ ${ }^{2}$ College of Veterinary Medicine and Agriculture, Post Box No: 34, Addis Ababa University, Ethiopia \\ ${ }^{3}$ Aklilu Lemma Institute of Pathobiology, Post Box No: 1176, Addis Ababa University, Addis Ababa, Ethiopia

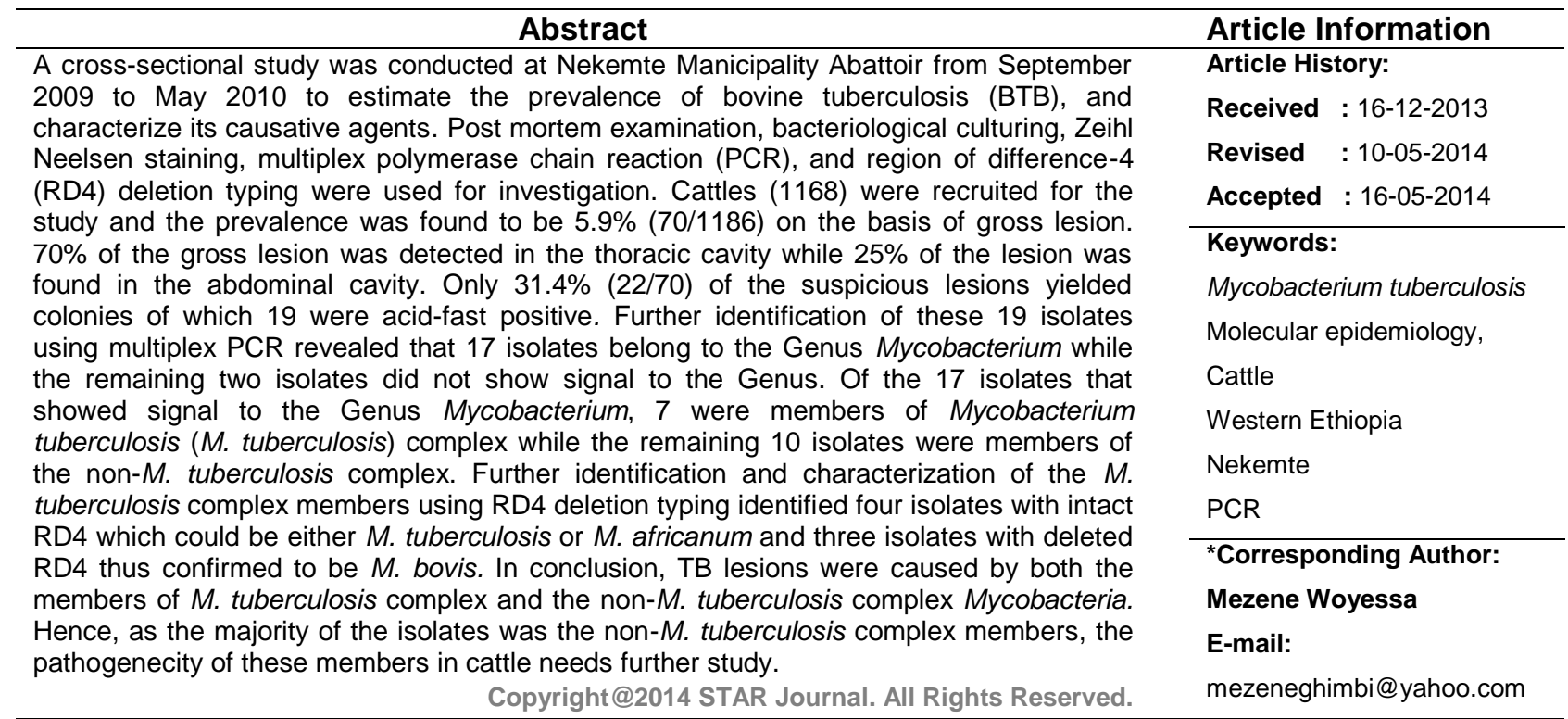

\section{INTRODUCTION}

Tuberculosis (TB) is still accounts for a large number of death and great morbidity Worldwide. The disease is most common in parts of the developing nations of the world. These countries have nearly two-third of the world livestock population, but produce less than the developed world's meat and milk production due to poor management and high prevalence of livestock diseases such as tuberculosis, mastitis and respiratory diseases, etc (FAO,1995).

Tuberculosis is one of the important disease not only due to its effect on animal production and productivity, but also due to its public health importance (O'Reily and Dabron, 1995). Tuberculosis is estimated to infect two billion people worldwide with eight million new cases and two million deaths per annum. Ninety five percent of tuberculosis cases occur in the poorer parts of the world. According to WHO (1993), tuberculosis is very serious and global emergency disease. This is due to many factors, which contribute to such problem, which are: 1), the synergy that exists between AIDS and tuberculosis. Currently $8-10 \%$ of the cases of tuberculosis are related to HIV infection; 2), the emergence of drug resistant and multi-drug resistant strain; and 3 ), many cases of tuberculosis occur in the third world where sanitation and health care are very poor; meaning the treatment of the disease is not carried out as effectively as in the rest of the world. In Africa, TB has received scanty attention mainly as a public health threat. The incidences of TB in human runs parallel to that of cattle, and it is increased by introduction of modern farming system together with risk of close contact with infected cattle in rural areas, the habitat of consumption of raw meat and milk from infected cattle and HIV/AIDS pandemic (Daborn \& Grange, 1993).

The potential for transmission of zoonotic tuberculosis, i.e., tuberculosis from animals to human occurs directly by aerosol and through the food chain by consumption of milk and meat from tuberculous cattle. Milk products such as yoghurt, cream and cheese were also noted to have contained tubercule bacilli several days after being manufactured from unpasturalized milk. As the main route of entry is oral rout, tuberculosis of bovine origin in man is mainly extra pulmonary resulting in bone and joint 
tuberculosis as well as infection of the cervical and mesenteric lymph nodes (Daborn and Grange, 1993; Edelsten, 1996).

Diagnosis of BTB is helpful to reduce the risk of zoonosis, together with increasing public awareness and proper hygienic in food chain from animal source which may result in eradication (Acha and Szyfres, 2001). Therefore definitive diagnosis can be achieved through isolating and typing the ethological agent through different diagnostic techniques (Acha and Szyfres, 2001).

The advent of genetic engineering has provided alternative DNA based strategies, which have the potential to overcome non-specific reactions. The development of agarose electrophoresis is for the size separation of DNA fragment, followed by the variability of restriction endonucleases which cleave DNA at defined sites lead to the development of restrictionfragment analysis of bacterial DNA; this technique produce a pattern of fragments or finger prints, which uniquely characterizes the strain from which DNA was isolated (Butcher et al., 1996).

Although national data is not available on the prevalence of BTB in Ethiopia, it is assumed that the incidence of the disease is rising because of the present private-oriented economic policy of the government, which thereby promotes the expansion of dairy industry. A few studies have been conducted in central highlands of Ethiopia on the epidemiology of BTB, and the results of such studies have indicated that the disease is prevailing in these areas (Ameni et al., 2003a, and Asseged et al., 2001). Such studies were carried out most commonly using tuberculin skin testing, abattoir meat inspection and rarely on bacteriological techniques. Therefore, expansion of similar studies to the untouched regions of the country will be useful towards made to establish the epidemiology of the disease at the national level. Moreover, complementing such studies with the application of molecular tools so as to identify and characterize the species and strains of Mycobacteria that are pathogenic to cattle is of paramount importance. The current study was formulated to estimate the prevalence, to evaluate the distribution of lesion and to isolate and characterize Mycobacteria from suspicious TB lesions slaughtered at Nekemete Manicipality Abattoir, Western Ethiopia.

\section{MATERIALS AND METHODS}

\section{Study Area}

The study was conducted from September, 2009 to May, 2010 in Western part of Ethiopia at Nekemet municipality abattoir. The town (Nekemte) is located at $331 \mathrm{~km}$ West of Addis Ababa. The approximate geographical location of the area is between $9^{\circ} 4^{\prime} 7 \mathrm{~N}$ to $9^{\circ} 11^{\prime} 02 \mathrm{~N}$ and $36^{\circ} 30^{\prime} \mathrm{E}$ to $36^{\circ} 43^{\prime}$ O2E. The altitude is from $1500 \mathrm{~m}$ to $2565 \mathrm{~m}$ above sea level and the maximum temperature is $27.4^{\circ} \mathrm{C}$ and the minimum temperature of the area is about $10.2{ }^{\circ} \mathrm{C}$. The mean annual rainfall of the area ranges from $1600 \mathrm{~mm}$ to $2000 \mathrm{~mm}$. The area receives long heavy rainy season from June to September and short rainy season from March to May. Among the various soil types in the area, the red brown soil with a $\mathrm{PH}$ ranging from 5-7 is the predominant type of soil in the Zone. The area is rich in natural vegetation that comprised of the tropical rain forest tree, all grasses and brushes.

The abattoir is the only source of inspected beef in the town. The overall hygiene of the abattoir, including the drainage, water, lighting and condemned organ and carcass disposal system is medium. Animals from different origin of the surrounding district are the source for slaughtering.

\section{Study Design, Sample Collection and Transportation}

Cross-sectional study was followed for the survey to determine the prevalence of BTB in the study area. In a slaughter house about 10 heads of cattle on average was randomly selected from the total of animals slaughtered per day. Tissue lesion samples suspected to be positive for BTB was collected aseptically from the lung lobes, lymph nodes of the head, lung, intestine and other tissue and organs. These samples collected from the abattoir were kept at $4{ }^{\circ} \mathrm{C}$ in the refrigerator for $5-10$ days and transported to Akililu Lemma institute of Pathobiology in ice box packed with ice packs to keep the low temperature during transportation for culture.

The sample size calculation was based on $50 \%$ prevalence assumption, $95 \% \mathrm{Cl}$ and $P<0.05$ (Thrusfeild, 2005). Therefore, the sample size calculated was 384

$$
\frac{n=Z^{2} \cdot p_{\text {expe. }}\left(1-p_{\text {expe. }}\right)}{d^{2}}
$$

Where $\mathrm{n}=$ required sample size

$P$ expe. =expected prevalence

$\mathrm{d}=$ Desired absolute precision $(5 \%)$

$Z=$ Normal distribution constant

\section{Ante Mortem Examination}

Physical examination of the animals were carried out before they were slaughtered. Body temperature, pulse rate, respiratory rate, condition of superficial lymph nodes and visible mucus membranes were examined and recorded for individual animals to be slaughtered. Breed and sex was also recorded. Age was estimated as described by Amstutz, 1998 and Body Condition Scoring (BCS) chart was made based on the description by Nicholson and Butterworth, 1986.

\section{Post Mortem Examination in Abattoir}

Meat inspection for TB lesion detection was conducted in accordance with the method developed by meat inspection and quarantine division of the ministry of Agriculture (MOA). It involves palpation and incision of the lung, liver and udder, visual inspection of the kidney, palpation and incision of the trachobronchial, mediastinal, prefemoral and prescapular lymph nodes. If lesion is recovered in the above tissue, other lymph nodes and tissues are incised (Teklu et al., 2004). Lymph nodes were sliced in to thin section of $2 \mathrm{~mm}$ and other tissues were cut in to slices of $2 \mathrm{~cm}$ using separate sterile surgical blades. The cut surface was examined under a bright light source for the presence of abscess and tubercules (Patterson and Grooms, 2000; Asseged et. al., 2004). In the presence of suspected tuberculous lesions tissue sample were collected in the universal bottles containing normal saline $(0.85 \%)$ for culture. In the presence of lesions in different tissues of single animal, pooled sample for each animal collected.

\section{Isolation and Identification}

Tissue samples were transported in the cold chain using ice box packed with ice packs to keep the low temperature. Then the tissue samples were macerated in sterile mortar and pistol using surgical blades and forceps to get fine pieces and then homogenized for 10 minutes in $5 \mathrm{ml}$ of normal saline. Two $\mathrm{ml}$ of homogenate were 
Mezene et al.,

transferred to centrifuge tube and decontaminated with equal volume $(2 \mathrm{ml})$ of $4 \% \mathrm{NaOH}$ for 15 minutes; centrifuged at $3000 \mathrm{rpm}$ for 15 minutes and neutralized by $1 \% \mathrm{HCL}$, employing phenol red as an indicator. Neutralization was achieved when the suspension changed from purple to yellow. After neutralization, $0.1 \mathrm{ml}$ of the suspension from each sample was spread on slants of Lowenstein-Jensen (LJ). Each sample was inoculated on to the set of Lowenstein-Jensen (LJ-pyruvate) and glycerol (standard LJ). Cultures were incubated aerobically at $37{ }^{\circ} \mathrm{C}$ for up to 12 weeks with weekly observation for growth. When visible colonies were observed, Zeil-Neelsen staining was performed to confirm the presence of acid fast bacilli (WHO, 1998; Quinn et al., 2002).

\section{Microscopic Examination}

A direct smear was prepared from pure colony grown on L-J media and stained using the Zeihl-Neelsen acidfast staining technique; the heat fixed smear were stained with carbonfucisn, heated gently and allowed to stand for 10 minutes. The stain was then poured off and the smears washed with tap water and then decolorized with acidic alcohol for 1 minute, each with the slides being washed under tap water between each step. The smears were then counter stained with methylene blue for 3 minutes, were dried and examined for the presence of AFB under light microscope employing a 100X oil immersion objective (Quinn et. al., 2002).

\section{Molecular Characterization of Mycobacteria Polymerase Chain Reaction (PCR)}

Initial identification of Mycobacterial species was based on the rate of growth, pigment production and colony morphology. For further characterization of the species molecular technique was used. The Mycobacteral cell from culture colony was killed in $80^{\circ} \mathrm{C}$ water bath for 1 hour and the DNA was extracted according to ALIPB-TBMolecular biology/Immunology laboratory standard operation procedure (SOP) from the Mycobacterial culture isolates (Jordan and Victor, 2002).

\section{Multiplex Polymerase Chain Reaction (m-PCR)}

For multiplex PCR, the procedure described by Wilton and Cousins (1992) was followed. This multiplex PCR differentiates $M$. tuberculosis complex from $M$. avium, $M$. intracellularae and other Mycobacterial species, and either heat-killed bacterial suspensions or extracted DNA was used. The PCR targets the sequence of the Genus Mycobacterium within the 16S rRNA gene (G1, G2), sequences within the hyper-variable region of $16 \mathrm{~S}$ rRNA that is known to be specific to $M$. intracellularae (MYCINT$\mathrm{F}$ ) and $M$. avium (MYCAV-R), and the MTB70 gene specific for $M$. tuberculosis complex (TB-1A, TB-1B). The primers used were MYCGEN-F, 5'AGA GTT TGA TCC

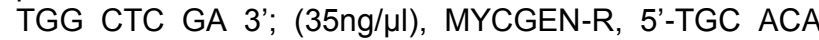
CAG GCC ACA AGG GA 3', (35ng/ $\mu \mathrm{l})$; MYCAV-R, 5'-ACC

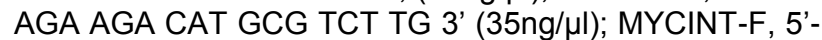

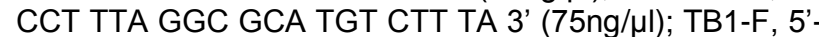
GAA CAA TCC GGA GTT GAC AA 3' (20ng/ $\mu \mathrm{l})$; TB1-R, 5'-AGC ACG CTG TCA ATC ATG TA 3' (20ng/ul). The reaction was carried out using Thermal Cycler. The mixture was heated for $10 \mathrm{~min}$ at $95{ }^{\circ} \mathrm{C}$, further 35 cycles of $1 \mathrm{~min}$ at $95{ }^{\circ} \mathrm{C}, 1 \mathrm{~min}$ at $61{ }^{\circ} \mathrm{C}$, and $1.5 \mathrm{~min}$ at $72{ }^{\circ} \mathrm{C}$; and $10 \mathrm{~min}$ at $72{ }^{\circ} \mathrm{C}$. Each PCR tube consisted of $5.2 \mu \mathrm{l}$ $\mathrm{H}_{2} \mathrm{O}$ Qiagen, $8 \mu \mathrm{l} \mathrm{HotStarTaqMasterMix,} 0.3 \mu \mathrm{l}$ of each of the six primers (concentration given above), $5 \mu$ l of DNA templates of samples or controls making the total volume

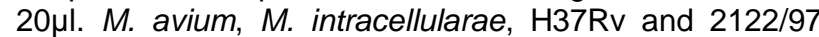

Sci. Technol. Arts Res. J., April-June 2014, 3(2): 167-173

(M. bovis strain) were used as positive controls while $\mathrm{H}_{2} \mathrm{O}$ Qiagen, was as a negative control. The product was electrophorized in $2 \%$ agarose gel in TAE running buffer. SYBR Safe at a ratio of $1: 10$ in $2 \%$ agarose gel, $100 \mathrm{bp}$ DNA ladder, and orange $6 x$ loading dye were used in gel electrophoresis. All members of the Genus Mycobacterium produce a band of $1030 \mathrm{bp}$, M. avium or subspecies such as $M$. avium subspecies paratuberculosis produces a band of $180 \mathrm{bp}, M$. intracellularae a band of $850 \mathrm{bp}$ while members of $M$. tuberculosis complex produce a band with 372bp.

\section{RD4 Deletion Typing}

The RD4 deletion typing was applied to isolates that showed band for $M$. tuberculosis complex by multiplex PCR. The primers used were RD4intF, 5'-ACA CGC TGG CGA AGT ATA GC-3'; RD4flankR, 5'-AAG GCG AAC AGA TTCAGC AT-3'; and RD4falnkF, 5'-CTC GTC GAA GGC CAC TAA AG-3'. The mixture was heated in Thermal Cycler for $15 \mathrm{~min}$ at $95^{\circ} \mathrm{C}$, and then subjected to 35 cycles of $1 \mathrm{~min}$ at $95^{\circ} \mathrm{C}, 1 \mathrm{~min}$ at $55^{\circ} \mathrm{C}$, and $1 \mathrm{~min}$ at $72{ }^{\circ} \mathrm{C}$; and $10 \mathrm{~min}$ at $72{ }^{\circ} \mathrm{C}$. Each PCR tube consisted of $7 \mu \mathrm{H}_{2} \mathrm{O}$ Qiagen, $10 \mu \mathrm{l} \mathrm{HotStarTaqMasterMix,} 0.3 \mu \mathrm{l}$ of each of the six primers (concentration), $2 \mu \mathrm{l}$ of DNA templates of samples or controls making the total volume $20 \mu \mathrm{l}$. H37Rv and 2122/97 ( $M$. bovis strain) were used as positive controls while $\mathrm{H}_{2} \mathrm{O}$ Qiagen, was used a negative control. The product was electrophoresed in $1.5 \%$ agarose gel in TAE running buffer 10X. SYBR Safe at a ratio of $1: 10$ in $2 \%$ agarose gel, 100bp DNA ladder, and orange $6 x$ loading dye were used in gel electrophoresis. The gel was read using SYNGENE BIO IMAGING SYSTEM (A Division of Syoptics Group). The presence of RD4 (i.e. $M$. tuberculosis and $M$. africanum) gives a product size of 335bp (RD4 intF + RD4flankR) its absence ( $M$. bovis) gives a product size of 446bp (RD4flankF + RD4flankR).

\section{Data Analysis}

During the study, individual animal identification number, place of origin, breed, sex, age, organ or tissue affected at abattoir and cultural, staining, PCR and spoligotyping results of laboratory work were entered into MS Excel data sheets. Then, coded and were analyzed using SPSS version 16 statistical software. The prevalence rate was calculated by dividing the proportion of cattle found infected (either positive reactors or harbouring tuberculous lesions) by the total number of cattle tested or whose carcasses is inspected multiplied by $100 \%$. The risk factors associated with $M$. bovis infection were calculated by using Chi-square $\left(\chi^{2}\right)$ and logistic regression. Odds Ratio (OR) was assessed to investigate the strength of association. A statistically significant association between variables was said to exist if the calculated $P<0.05$. For the analysis of the effect of different risk factors on bovine tuberculosis status of animals, doubtful reactors were not considered as positive (Thrusfeild, 2005).

\section{RESULTS}

\section{Results of Abattoir Survey}

The prevalence of BTB was investigated and was found to be $5.9 \%$ in abattoir-based surveillance. As shown below, the prevalence of BTB in different district of the study area was different. High prevalence was observed in Guto-gida (11.5\%) and low prevalence was recorded in Wayu-Tuka. In the remaining part of animal origin the prevalence is almost similar (Figure 1). 


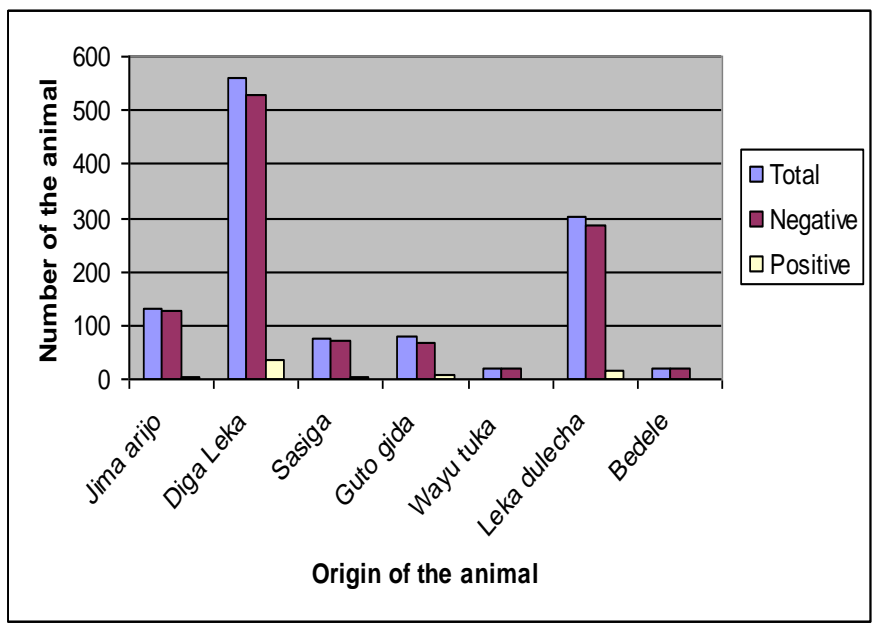

Figure 1: Prevalence of bovine tuberculosis in different district of animal origin

From the risk factors considered (Table 1), only breed was found significantly associated with BTB infection $(P<0.05)$ and the rest were not found significantly associated with the presence of gross tuberculous lesions ( $P>0.05)$.

Table 1: Level of association of various host and environmental risk factors with $M$. bovis infection

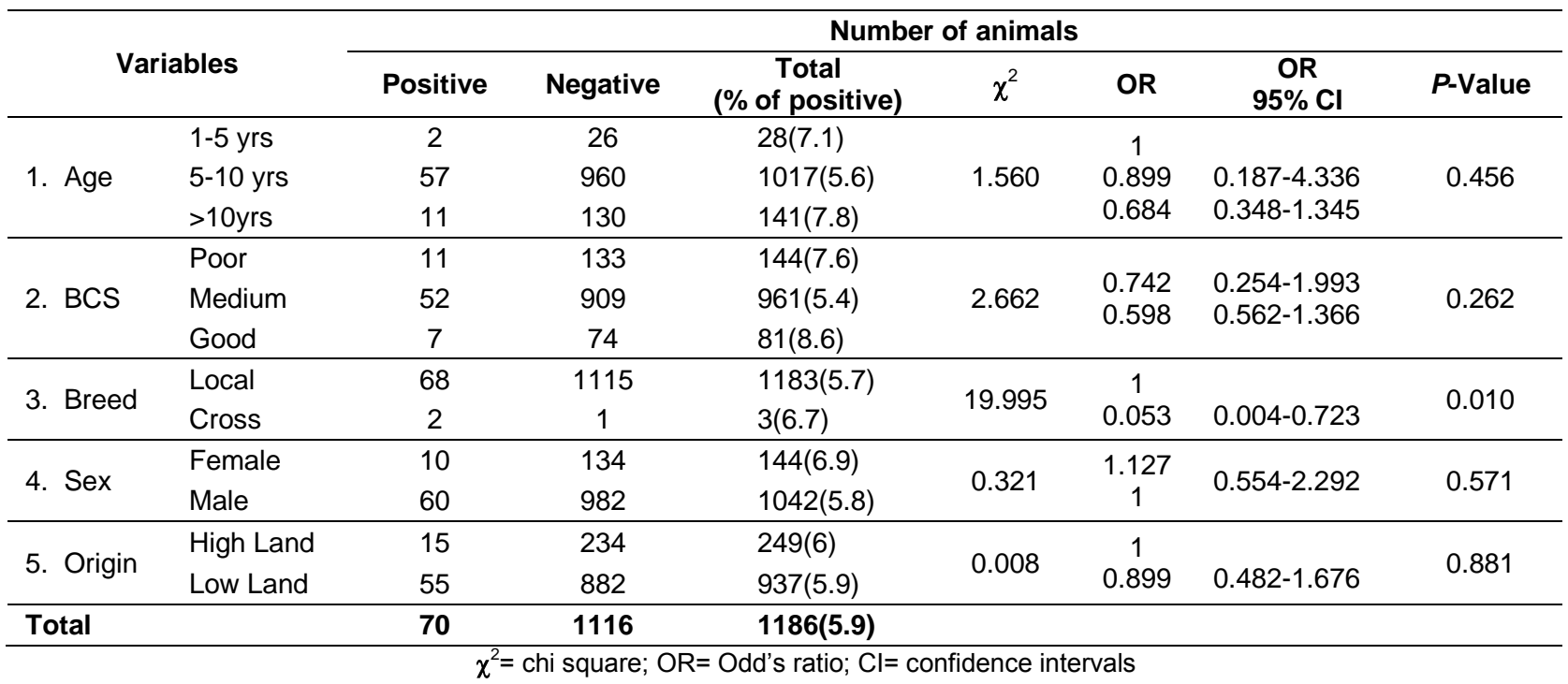

The distributions of tuberculous lesions in tissues of positive animals were presented in Table 2. The entire lesions observed were localized lesions involving frequently a single organ. A high proportion $(70 \%)$ of the lesions was located on the thoracic cavity lymph nodes, while 25.7 and $4.3 \%$ of the lesions were found in the abdominal cavity and head regions respectively.

Table 2: The distribution of tuberculous lesion in the tissues of infected animals

\begin{tabular}{llcc}
\hline \multicolumn{1}{c}{ Region of the body } & \multicolumn{1}{c}{ Anatomic site } & $\begin{array}{c}\text { Number of } \\
\text { infected tissue }\end{array}$ & \% of positive \\
\hline \multirow{3}{*}{ Head } & Mandibular LN & 2 & 2.9 \\
& Retropharyngeal LN & 1 & 1.4 \\
\cline { 2 - 4 } & Total & $\mathbf{3}$ & $\mathbf{4 . 3}$ \\
\hline \multirow{4}{*}{ Thoracic cavity } & Cranial mediastinal LN & 21 & 30.0 \\
& Caudal mediastinal LN & 14 & 20.0 \\
& Left bronchial LN & 11 & 15.7 \\
& Right bronchial LN & 3 & 4.3 \\
\cline { 2 - 4 } & Total & $\mathbf{4 9}$ & $\mathbf{7 0}$ \\
\hline \multirow{3}{*}{ Abdominal cavity } & Mesenteric LN & 17 & 24.3 \\
& Hepatic LN & 1 & 1.4 \\
\cline { 2 - 4 } & Total & $\mathbf{1 8}$ & $\mathbf{2 5 . 7}$ \\
\hline
\end{tabular}


Mezene et alo,

\section{Bacteriology}

From 70 tuberculous suspected tissue samples on postmortem inspection, that transported ALIPB, at different laboratory entry batch, showed $31.4 \%(22 / 70)$ growth on primary culture media. The outcome of the
Sci. Technol. Arts Res. J., April-June 2014, 3(2): 167-173

culturing activity is indicated in table 3 . Among those cultures which showed visible grows, only $31.8 \%(7 / 22)$ were on L-J media enriched with pyruvate and the rest $68.2 \%(15 / 22)$ were on L-J media enriched with glycerol (Table 3).

Table 3: Cultural result of tuberculous tissues from slaughtered cattle

\begin{tabular}{|c|c|c|c|c|}
\hline \multirow{3}{*}{ Sample type } & \multicolumn{4}{|c|}{ Growth on } \\
\hline & \multicolumn{2}{|c|}{ L-J media with Glycerol } & \multicolumn{2}{|c|}{ L-J media with Pyruvate } \\
\hline & Total & Positive (\%) & Total & Positive (\%) \\
\hline Bronchial LN & 14 & $2(14.3)$ & 14 & $1(7.1)$ \\
\hline Mediastinal LN & 35 & $8(22.9)$ & 35 & $5(14.3)$ \\
\hline Mesenteric LN & 17 & $5(29.4)$ & 17 & - \\
\hline Mandibular LN & 2 & - & 2 & $1(50)$ \\
\hline Retropharyngeal LN & 1 & - & 1 & - \\
\hline Hepatic LN & 1 & - & 1 & - \\
\hline Total & 70 & $15(68.2)$ & 70 & $7(31.8)$ \\
\hline
\end{tabular}

The total of 22 grown cultures were subjected to ZeihlNeelsen staining technique in the laboratory in order to check for the presence of acid fast bacilli organisms. Out of these, only $13.6 \%(3 / 22)$ were acid fast negative. The remaining 19 grown culture media were confirmed for the presence of acid fast bacilli.

\section{Molecular Analysis}

From 19 cultures, positive colonies obtained were from tuberculous tissue samples, up on multiplex PCR, 17 of them showed for the presence of the genus mycobacteria. The remaining 2 isolats didn't show the amplification products characteristic to mycobacterium (Figure 2), by using the genus specific primers MYCGEN-F (5'-AGA GTT TGA TCC TGG CTC AG3') and MYCGEN-R (5'-TGC ACA CAG GCC ACA AGG GA-3').

\section{RD4 Deletion Typing}

The results of $\mathrm{m}-\mathrm{PCR}$, which showed band were subjected to RD4 deletion typing. The PCR reaction gave a product size of $335 \mathrm{bp}$ for 4 isolates indicating the presence of RD4 and hence the isolates could be either M. tuberculosis or M. Africanum. A product size of $446 \mathrm{bp}$ was produced for 3 isolates indicating the absence of RD4 and therefore, it was confirmed to be $M$. bovis (Figure 3 )

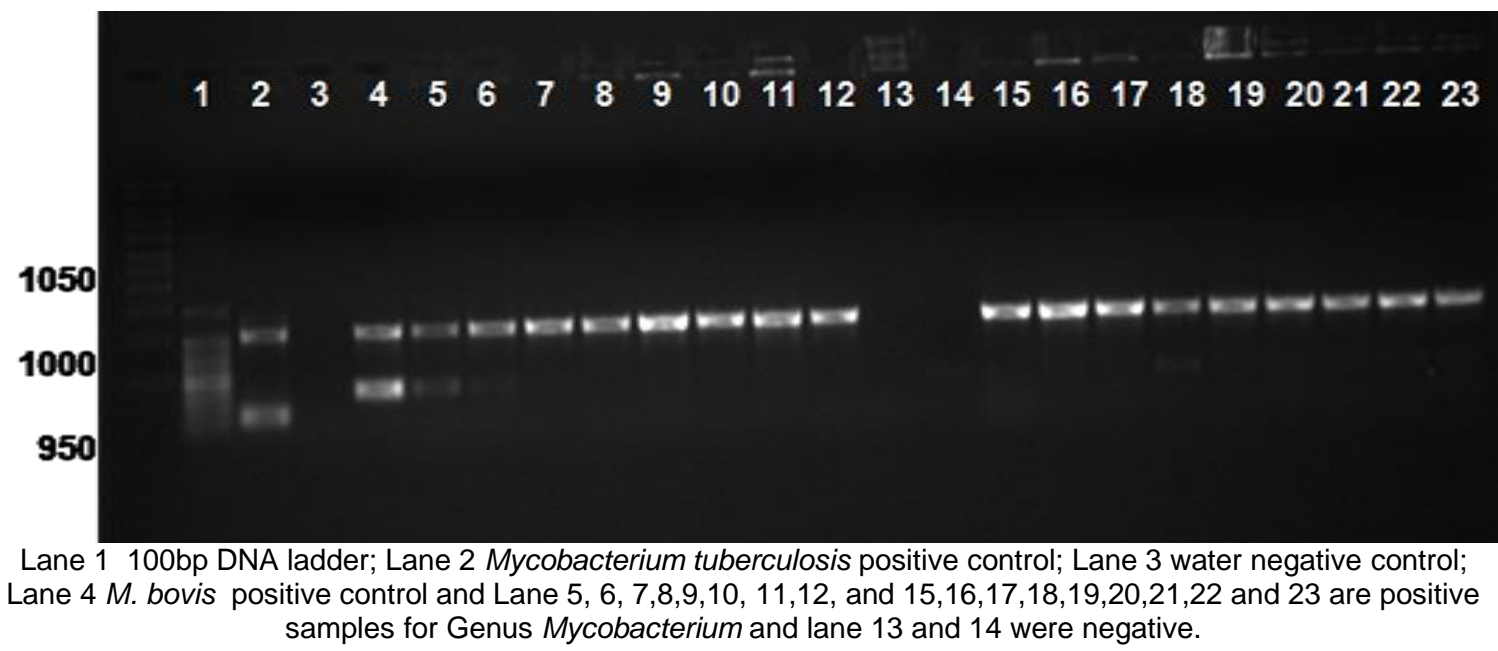

Figure 2: Electrophoretic separation of PCR products by multiplex typing of Mycobacteria isolated from tissue samples

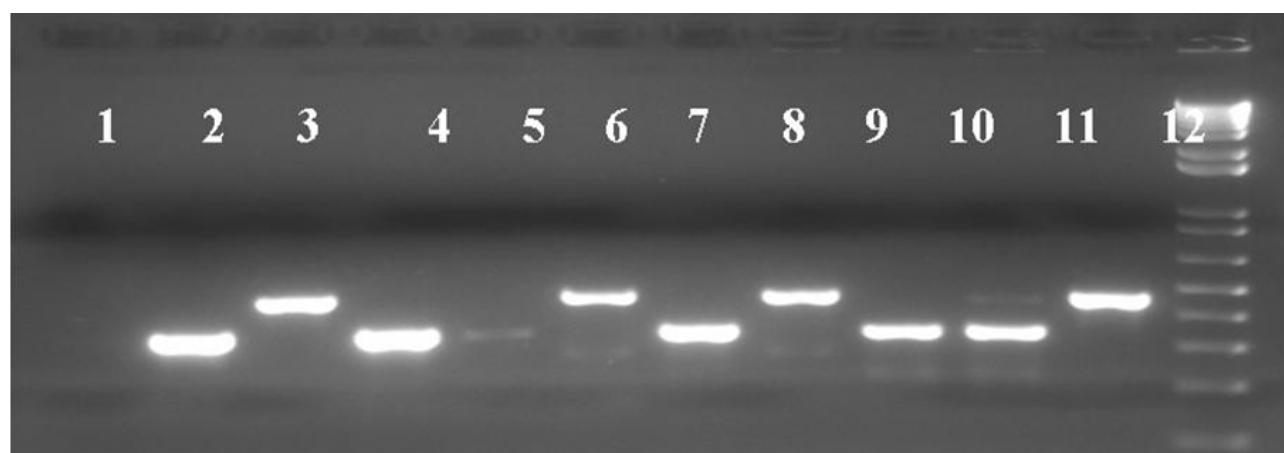

Lane 1 Negative control, Lane 2 and Lane $3 M$. tb, M. bovis positive control respectively; Lane 4, 7, 9 and 10 templates DNA $M$. tb or $M$ africanium; Lane 6, 8 and 11 templates DNA of $M$. bovis

Figure 3: Electrophoretic separation of PCR products by RD4 deletion typin 


\section{DISCUSSION}

The overall prevalence of BTB $(5.9 \%)$ obtained in the current abattoir survey was high when compared with Regassa et al, 2009 (1.1\%) at Hawassa, Asseged et al., 2004 (1.48\%) in Addis Ababa, Shitaye et al., 2006 (3.46\%) in Addis Ababa and Teklu et al.,2004 (4.53\%) at Hossana through similar diagnostic methods but in consistence with previous reports of Ameni and Wudie, 2003b (5.16\%) from Adama Manicipaliy abattoir, Gudeta, 2008 from Nekemte Manicipality abattoir (5.1\%) and Desta, $2008(5 \%)$ at Kombolch meat processing plant, Southern Wallow, based on postmortem inspection. However, the presently recorded prevalence was low as compared to previous report by Shimels, 2008 at Debre Brihan, Central Ethiopia and Reggasa, 1999 (7.96\%) at Wolaita Sodo. The infection rate in cattle has been found to differ greatly from place to place (Shitaye et al., 2006) and the difference might be most probably linked to the type of production system (most notably in extensive), which is unlikely to favor the spread of the disease in contrast to the intensive dairy farms as cited by Ameni et al., 2006 and Shitaye et al., 2006.

There was statistical significant $\left(\chi^{2}=19.9\right.$ and $\left.P=0.010\right)$ difference between breed of the animal and tuberculous lesion. Radostitis et al., 1994 has indicated that Zebu breeds are relatively resistant for BTB than exotic breeds. The remaining assumed risk factors both in abattoir survey and comparative intradermal test revealed no statistical significant difference. The possible reason might be due to in proportionality in the number of the animal compared in specific variable. For example, less number of female animals were came to the study abattoir to be slaughtered and the proportion of very young animal and animal with lean body condition encountered in abattoir was low. However, there is biological association as observed from the Odd's ratio value.

In the present study, gross tuberculous lesions were found most frequently in lymph nodes of the thoracic cavity $(70 \%)$; followed by lymph nodes of the abdominal cavity $(25.7 \%)$ and the lesser frequency was found in the lymph nodes of the head region (4.3\%). The occurrence of tuberculous lesions in thoracic cavity was lower than the results of previous studies, wher greater than $90 \%$ occurrence of TB lesions in the respiratory system was reported in developed countries (Neill et al., 1994; Collins, 1996; Whipple et al., 1996). However it is higher than the report of Regassa et al., 2009 which implies that inhalation is the most important rout of infection. Husbandry factors such as enclosures of the animals overnight may facilitate respiratory transmission of the infection (WHO, 2005). The followed high proportion in lymph nodes of the abdominal cavity indicate, the other important route of transmission is ingestion of the agent which may happen during the suckling time from the infected dams or by licking, feeding or drinking contaminated materials (Hardie and Watson, 1992; Morris et al., 1994; Smyth et al., 2001).

In the current study, the chance of growing Mycobacteria was less than $50 \%$ which might be due to either loss of the agent during freezing or delayed transportation from the site of collection. WHO (1998) indicated loss of $5-10 \%$ due to contamination resulting from prolonged preservation, which in turn resulted into, overgrowth of $M$. bovis with environmental Mycobacteria and a loss of up to $60 \%$ due to decontamination procedure. Besides, $M$. bovis grows poorly on standard
Löwenstein-Jensen medium (Cleaveland et al., 2007). Therefore, the use of proper time in culturing and application of standard laboratory technique could increase the chance of recovery of acid fast bacilli. However, the result was higher than the previous report (Araujo et al., 2005) were only 17 isolates obtained from $72(23.6 \%)$ lesion positive samples and in agreement with the report (32\%) of Shimels, 2008.

Molecular analyses of the isolates were revealed that the lesions were caused not only by the members of $M$. tuberculosis complex but also by members of the non- $M$. tuberculosis group. Even majority of the isolates belonged to the later group. Similar results were reported by other workers in Ethiopia (Berg et al., 2009). The techniques employed by the present study could not further identify these isolates to the species level.

\section{CONCLUSIONS}

The result of the present study has shown that bovine tuberculosis is prevalent in cattle slaughtered at Nekemte Abattoir. Even though, majority of the isolates were non$M$.tuberculosis members, it was observed that the lesions were caused by Mycobacteria that belongs to both $M$. tuberculosis complex and non-M. tuberculosis complex group. This may be due to contamination of an environment in which they belong (particularly pasture and water body), through faces and air droplet. In addition to this people of the area have the habit of consuming raw meat and milk and share the same microenvironment with their livestock. This further disseminates the causative agent, both through inhalation and ingestion resulting in high economic loss and public health effect. This study reveals a high proportion of tuberculous lesion in the thoracic cavity lymph nodes (70\%). It implies that respiratory rout is the major means of transmission. Similar studies, in the slaughterhouse across the country so as to estimate the national prevalence of BTB as well as identification and characterization of the non- $M$. tuberculosis complex, and evaluation of their pathogencity in bovine is essential. Detailed abattoir inspection should be implemented by focusing on lymph nodes of the thoracic, mesenteric and head region. Finally Public education to increase the awareness of the community about the potential risk of consumption of raw animal products is necessary.

\section{ACKNOWLEDGEMENTS}

It is my pleasure to acknowledge Aklilu Lemma Institute of Pathobiology for financial and logistic support. I also acknowledge Nekemte Municipality Abattoir and Veterinary Clinic for their support during this research.

\section{REFERENCES}

Acha, P.N. and Szyfres, B. (2001). Zoonotic tuberculosis. In: Zoonoses and communicable diseases common to man and animals. $3^{\text {rd }}$ ed. Volume 1, Pp. 283-299.

Ameni, G., Bonnet, P. and Tibbo, M. (2003a). A crosssectional study on bovine tuberculosis in selected dairy farms in Ethiopia. International Journal of Applied Research in Veterinary Medicine 1(4):253-258.

Ameni, G. and Wudie, A. (2003b). Preliminary study on bovine tuberculosis in Nazareth Municipality Abattoir of central Ethiopia. Bulletin of Animal Health and Production in Africa 51:125-132.

Ameni, G., Aseffa, A., Engers, H., Young, D.B., Hewinson, G. R., Vordermeier, M.H. (2006). Cattle husbandry is a predominant factor affecting the pathology of bovine 
Mezene et alo,

tuberculosis and IFN-gamma responses to Mycobacterial antigens. Clinical and Vaccine Immunology 13(9):10301036.

Amstutz, H.E. (1998): Dental development. 8th Edition, Merck Veterinary Manual, Philadelphia, Pp 131-133.

Araújo C.P., Leite, C.Q., Prince, K.A, Jorge Kdos, S., Osório, A.L. (2005). Mycobacterium bovis identification by molecular method from post- mortem inspected cattle obtained in abattoirs of Mato Grosso do sul, Brazil. Memórias do Instituto Oswaldo Cruz 100(7):749-752.

Asseged, B., Lubke-Beker, A., Lemma, E., Kiros, T. and Britton, S. (2001). Bovine tuberculosis: A cross sectional and epidemiological study in and around Addis Ababa. Bulletin Animal Health and Production in Africa 48:71-80.

Asseged, B., Woldesenbet, Z., Yimer, E. and Lemma, E. (2004). Evaluation of abattoir inspection for the diagnosis of Mycobacterium bovis infection in cattle at Addis Ababa abattoir. Tropical Animal Health and Production 36:537 546.

Berg, S. Firdessa, R., Habtamu, M., Gadisa, E., Mengistu, A., Yamuah, L., Ameni, G., Vordermeier, M., Robertson, B., Smith, N., Engers, H., Young, D., Hewinson,R., Asseffa A. and Gordon, S. (2009): The burden of Mycobacterial disease in Ethiopian cattle: Implications for public health. PLOS ONE 4(4): 5068-76.

Butcher, P.D., Hutchinson, N.A., Doran, T.J., Dale, J.W. (1996). The application of molecular techniques to the diagnosis and epidemiology of Mycobacterial diseases. Journal of Applied Bacteriology 81:53-71.

Cleaveland, S., Shaw, D.J., Mfinanga, S.G., Shirima, G. Kazwala, R.R., Eblate, E. and Sharp, M. (2007). Mycobacterium bovis in rural Tanzania: Risk factors for infection in human and cattle populations. Tuberculosis 87:30-43

Collins, J.D. (1996). Factors relevant to M. bovis eradication. Irsh Veterinary Journal 49:241-243.

Daborn, C. and Grange, J.M. (1993): HIV/ AIDS and its implications for the control of Animal tuberculosis. Brazil's Veterinary Journal., 49: 405-417.

Desta, F. (2008). Study on mycobacterium bovis using conventional and molecular methods in cattle slaughtered in Kombolicha ELFORA meat processing plant. M.Sc, Thesis, Addi Ababa University, Ethiopia.

Edelsten, R.M. (1996). Tuberculosis in cattle in Africa, control measures and implication for human health. In: Linderbrge, R.(ed) Veterinary medicine impacts on human health and nutrition in Africa. Proceeding of the International Conference at the international Livestock research Institute (ILRI). Addis Ababa, Ethiopia.

FAO (1995). Livestock development strategies for low income counties. Proceeding of the joint ILRI/FAO round table on livestock development strategies for low income counties, Addis Ababa, Ethiopia.

Gudeta, T., (2008). Preliminary study on bovine tuberculosis in Nekemte municipality abattoir, Western Ethiopia. DVM Thesis, Jimma University, College of agriculture and School of Veterinary Medicine, Jimma, Ethiopia.

Hardie, R.M. and Watson, J.M. (1992). Mycobacterium bovis in England and Wales. Past, present and future. Epidemiology and Infection. 109:23-33.

Jordaan A. and Victor, (2002). Molecular biology techniques in the control of drug resistant tuberculosis. Protocols and SOP's. University of stellenbosch, South Africa, Pp 4-5.

Morris, R.S., Pfeifter, D.U. and Jackson, R. (1994). The epidemiology of Mycobacterium infection. Veterinary Microbiology 40: 153-177.
Sci. Technol. Arts Res. J., April-June 2014, 3(2): 167-173

Neill, S.D., Pollock, J.M., Bryson, D.B. and Hanna, J. (1994). Pathogenesis of Mycobacterium bovis infection in cattle. Veterinary Microbiology 40: 41-52.

Nicholson, M.J. and Butterworth, M.A. (1986). A guide to condition scoring zebu cattle. International livestock center for Africa (ILCA). Addis Ababa, Ethiopia, Pp72-74.

O'Relly, L.M. and Dabron, C.J. (1995). Epidemiology of Mycobacterium bovis infections in animals and man: A review. Tubercle and Lung Disease 76:1-46.

Patterson, J. and Grooms, D. (2000). Diagnosis of bovine tuberculosis: Gross Necropsy, Histopathology and Acid fast staining. Extension Bulletin 4:1-2.

Quinn, P.J., Carter, M.E., Markey, B. and Carters, G.R. (2002). Clinical Veterinary Microbiology. London, Mosby Year Book, Europe Ltd., Pp 156-169.

Radostits, D.M., Blood, D.C and Gay. C.C. (1994). Veterinary Medicine: Disease caused by Mycobacterium. In: A Text book of Disease of cattle, sheep, pig, Goats and Horses, $8^{\text {th }}(\mathrm{ed})$. Bailliere Tindal. London, Pp. 830-850.

Regassa, A., Tassew, A., Amenu, K., Megersa, B., Abunna, F., Mekibib, B., Macrotty,T. and Ameni G. (2009): A cross- sectional study on bovine tuberculosis in Hawassa town and its surroundings, southern Ethiopia. Tropropical Anim Health and Production 42 (5):915-920.

Shimels, S. (2008). Bovine tuberculosis: Epidemiological Aspects and Public health implications in and around debre- Brihan. M.Sc, Thesis. Addis Ababa University, Faculty of Veterinary Medicine. Debre-Zeiet, Ethiopia.

Shitaye, J. E., Getahun, B., Alemayehu, T., Skoric, M., Treml, F., Fictum, P., Virbas, V. and Pavilk, I. (2006). A prevalence study of bovine tuberculosis by using abattoir meat inspection \& tuberculin skin testing data, histopathological and IS6110 PCR examination of tissues with tuberculous lesions in cattle in Ethiopia. Veterinarini Medicina 51:512-522.

Symth, A.J., Welsh, M.D., Girvin, R.M., and Pollock, J.M. (2001). In vitro responsiveness of T-cells from Mycobacterium bovis infected cattle to mycobacterial antigens: predominant involvement of $\mathrm{WC1}^{+}$cells. Infection and Immunity 69:89-96.

Teklu, A., Asseged, B., Yimer, E., Gebeyehu, M. and Woldesenbet, Z. (2004). Tuberculous lesions not detected by routine abattoir inspection: the experience of the Hossana municipal abattoir, southern Ethiopia. Revue scientifique et technique 23: 957-964.

Thrustfield, M. (2005): Veterinary epidemiology, $3^{\text {rd }}$ edition Black well science, Oxford P.233.

Whipple, D.L., Bolin, C.A. and Miller, J.M. (1996). Distribution of lesion in cattle infected with Mycobacterium bovis. Journal Veterinary Diagnosis and Investigation 8:351-54.

WHO (1993). Report of the WHO meeting on zoonotic tuberculosis (Mycobacterium bovis). With the participation of FAO; Nov 15, 1993. Geneva, Switzerland.

WHO (1998). Laboratory services in tuberculosis control, Global Tuberculosis programme. World health Organization (WHO). Geneva, Switzerland.

WHO (2005). Global tuberculosis control surveillance: Planning and Financing. WHO Report, Country Profile, Ethiopia, 83-86.

Wilton, S. and Cousins, D. (1992). Detection and identification multiple Mycobacterial pathogens by DNA amplification in a single tube. PCR Methods and Applications 1(4): 269273. 